\title{
Intensity attenuation relation at Chamba-Garhwal area in north-west Himalaya with epicentral distance and magnitude
}

\author{
G K Ghosh ${ }^{1, *}$ and A K Mahajan ${ }^{2}$ \\ ${ }^{1}$ Oil India Limited, Duliajan, Assam 786 602, India. \\ ${ }^{2}$ Wadia Institute of Himalayan Geology, 33 GMS Road, Dehradun, India. \\ ${ }^{*}$ Corresponding author.e-mail: gk_ghosh@yahoo.com
}

\begin{abstract}
Seismic hazard assessment of any region depends on the attenuation relation which relates the seismological data with parameters of engineering interest. In the absence of sufficient strong motion data for northwest Himalayan region, isoseismal maps of previous earthquakes were the only source of information for computing the attenuation characteristics of that region. The northwest Himalayan region had experienced major and moderate earthquakes in the past and isoseismal maps had been developed by various authors for each of these earthquakes representing intensity pattern and decay of intensity in different directions. With this information, attenuation relations of intensity with distance can be obtained. The present study includes 10 moderate and major earthquakes $(M s \geq 4.9)$ that had occurred during the last 100 years. These are primarily Kangra (1905), Chamba-1 (1945), Chamba-2 (1995), Kinnaur (1975), Dharamsala (1986), Uttar Kashi (1991), Garhwal-1 (1996), Garhwal-2 (1996), Sundarnagar (1997) and Chamoli (1999) earthquakes. Miezoseismal zones in majority of the isoseismal maps show two major directions, i.e., either the longest axis of these isoseismal maps which are aligned in NW-SE direction following the major longitudinal features or north-northwest to south-southeast direction, following the tectonic features which are transverse to the Himalayan trend. Isoseismal maps of Kangra (1905), Chamba (1945) and Uttar Kashi (1991) earthquakes are more symmetrical and elongated in south-east direction, but compressed in north-east and north-west directions, thus indicating fast attenuation characteristics in north-east and north-west directions reflecting lithological variation. On the other hand, Sundernagar (1997) and Kinnuar (1975) earthquakes show circular pattern of intensity distribution. Combining decay patterns from different magnitude earthquakes in different directions, two attenuation relationships have been developed using regression relationship (least square method).
\end{abstract}

\section{Introduction}

Reliable estimates of seismic risk of any region need knowledge and understanding of both the seismicity and attenuation of strong seismic ground motion. A number of papers have been published on the seismicity status of northwest Himalaya and its isosesimal patterns. Even the seismic hazard zonation map of India is based on the damage effects observed from various earthquakes which occurred in the past. During the last one century (1905-2004), northwest Himalayan region has experienced many moderate and major earthquakes; however, the isoseismal maps of all those earthquakes were not well-documented. The present study aims at compiling the information of decay patterns from 10

Keywords. Attenuation; intensity; peak ground motion; epicentral distance. 
different earthquakes which occurred during the last 100 years (Kangra (1905), Chamba-1 (1945), Chamba-2 (1995), Kinnaur (1975), Dharamsala (1986), Uttar Kashi (1991), Garhwal-1 (1996), Garhwal-2 (1996), Sundarnagar (1997) and Chamoli (1999)) in the north-western Himalayan region. The information collected helps to draw intensity attenuation and its variation as a function of the distance with magnitude. These earthquakes have caused several indemnities and large fatalities in different parts of north-western India.

Seismologists have benefitted from the development of new instruments that can record ground motion of earthquake at higher dynamic range and broader bandwidth and the availability of advanced computers to analyse ground motion data. In this context, intensity is a historical expression which may not be important to a seismologist because the steps in an intensity scale are distinct by qualitative portrayal of the possessions of earthquake on buildings, people, ground surface; the result is that any linear relation derived from intensity distribution to ground motion parameters is fortuitous (Howel and Schultz 1975; Bakun and Wentworth 1999). To estimate earthquake hazard, strong motion data has utmost consequence in derivation of attenuation characteristics of that region. In the absence of such data, it is imperative to derive attenuation relations from historical earthquake intensity distribution which can represent attenuation characteristics of that region. Many studies on this topic have appeared in the literature and in most cases, the key role is played by the deterministic function which expresses the link between the intensity decay and factors such as epicentral distance. Sbar and Dubois (1984) derived the attenuation relation of northern Sonara region, North America using intensity distribution of normal fault earthquakes. They have derived three regression equations using intensity distribution within $25-500 \mathrm{~km}$. Similar attenuation relations have been derived for Eastern United States, Western United States, Cordillera and the San Andreas area (Howel and Schultz 1975; Gupta and Nuttli 1976; Bollinger 1977; Brazee 1976, 1979; Anderson 1978; Tilford et al. 1985). A few researchers (Chandra 1979; Chandra et al. 1979) also developed intensity attenuation relation with epicentral distance for different regions of Iran and compared the average attenuation intensities with San Andreas province.

The subject of intensity attenuation with distance has been studied extensively, but most investigators have focused only on the description of the mean trend and little or no attention has been paid to the scatter of observed data, although it is recognized that this scatter data is very important (e.g., Howel and Schultz 1975; Gupta and Nuttli 1976; Bollinger 1977). Similar works have been carried out by Sbar and Dubois (1984), Tilford et al. (1985), Atkinson and Mereu (1992), Ambraseys (1995, 2001), Bakun and McGarr (2002), Sokolov (2002), Zaré and Memarian (2003), Özbey et al. (2004), Bindi et al. (2006), Böse (2006), Parolai et al. (2006), Miao and Langston (2008), Sørensen et al. (2009), Stromeyer and Grünthal (2009) and Szeliga et al. (2010).

The present study determined the regression relations derived from the intensity attenuation with variable magnitudes at different epicentral distances. This can be useful in assessing damage

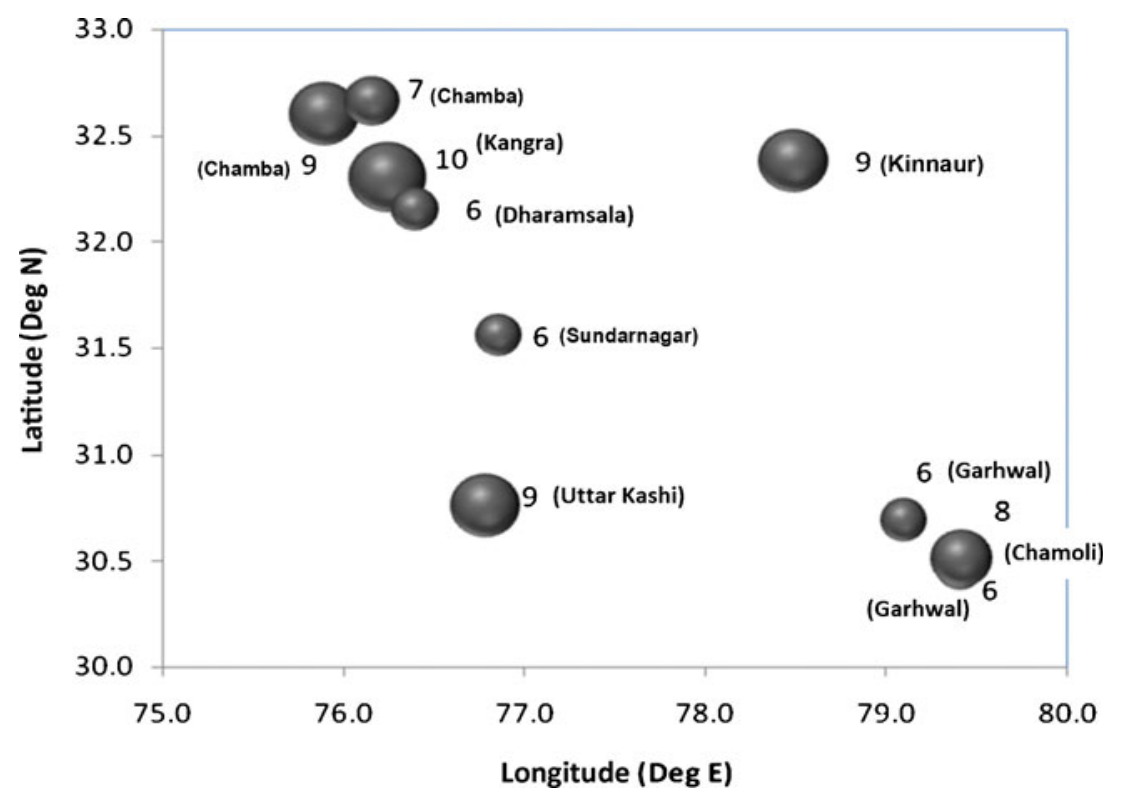

Figure 1. Intensity location map of different major earthquakes in the northwest Himalayan region. 


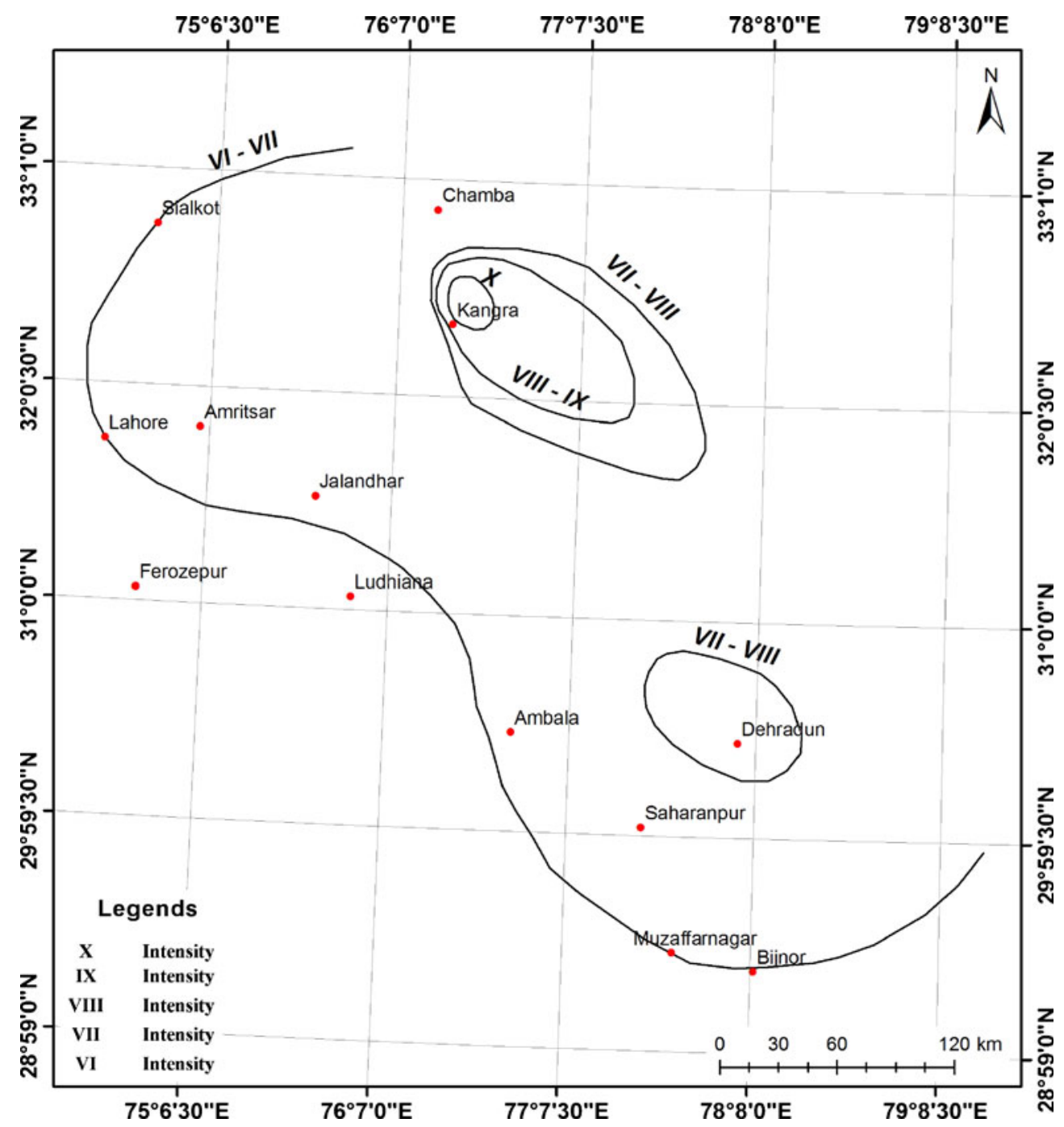

Figure 2(a). Isoseismal map of 1905 Kangra earthquake shows the fast attenuation pattern of seismic energy in the N-W part compared to the S-E part.

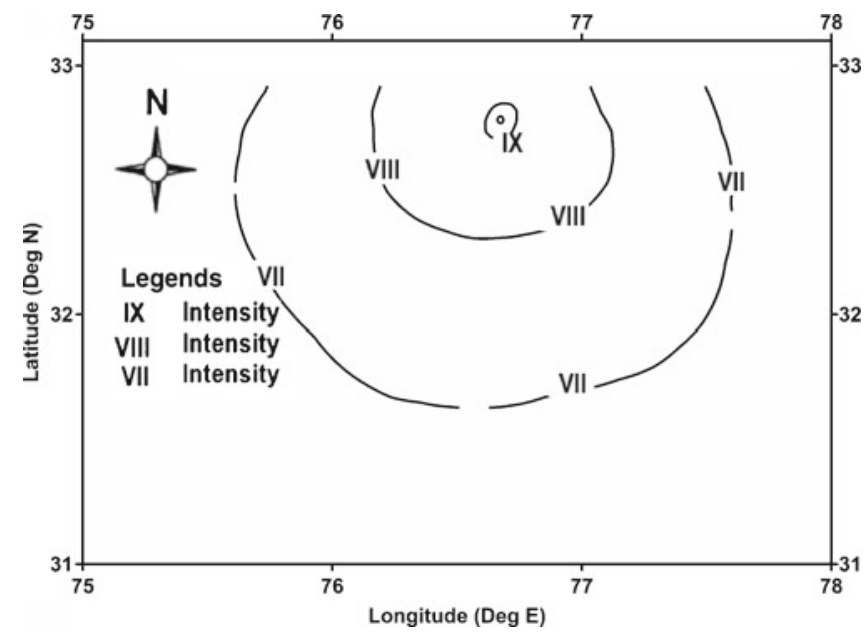

Figure 2(b). Isoseismal map of 1945 Chamba earthquake shows less attenuation in the $\mathrm{E}-\mathrm{W}$ direction compared to the $\mathrm{N}-\mathrm{S}$ direction. The maximum intensity was reported as IX, covering $7996.0 \mathrm{~km}^{2}$. for potential future earthquakes (earthquake scenario-based planning purposes) in the northwest Himalayan region of India.

\section{Tectonics of the area}

The on-going northward convergence of India produces active deformation in the Himalaya, Tibet and adjoining areas, keeping the entire region seismically active. The Himalayan mountain arc and the adjoining Shillong plateau and western Assam experienced four major and great earthquakes of magnitude $M w \geq 8.0$ within the last 110 years, namely, western Assam (1897), Kangra earthquake (1905), Bihar-Nepal (1934) and eastern Assam (1950). Of these, the Kangra earthquake (1905) caused 20,000 deaths (Middlemiss 1910). Arya (1990) forecasted that, if Kangra earthquake (1905) reoccurs with same magnitude and in the 


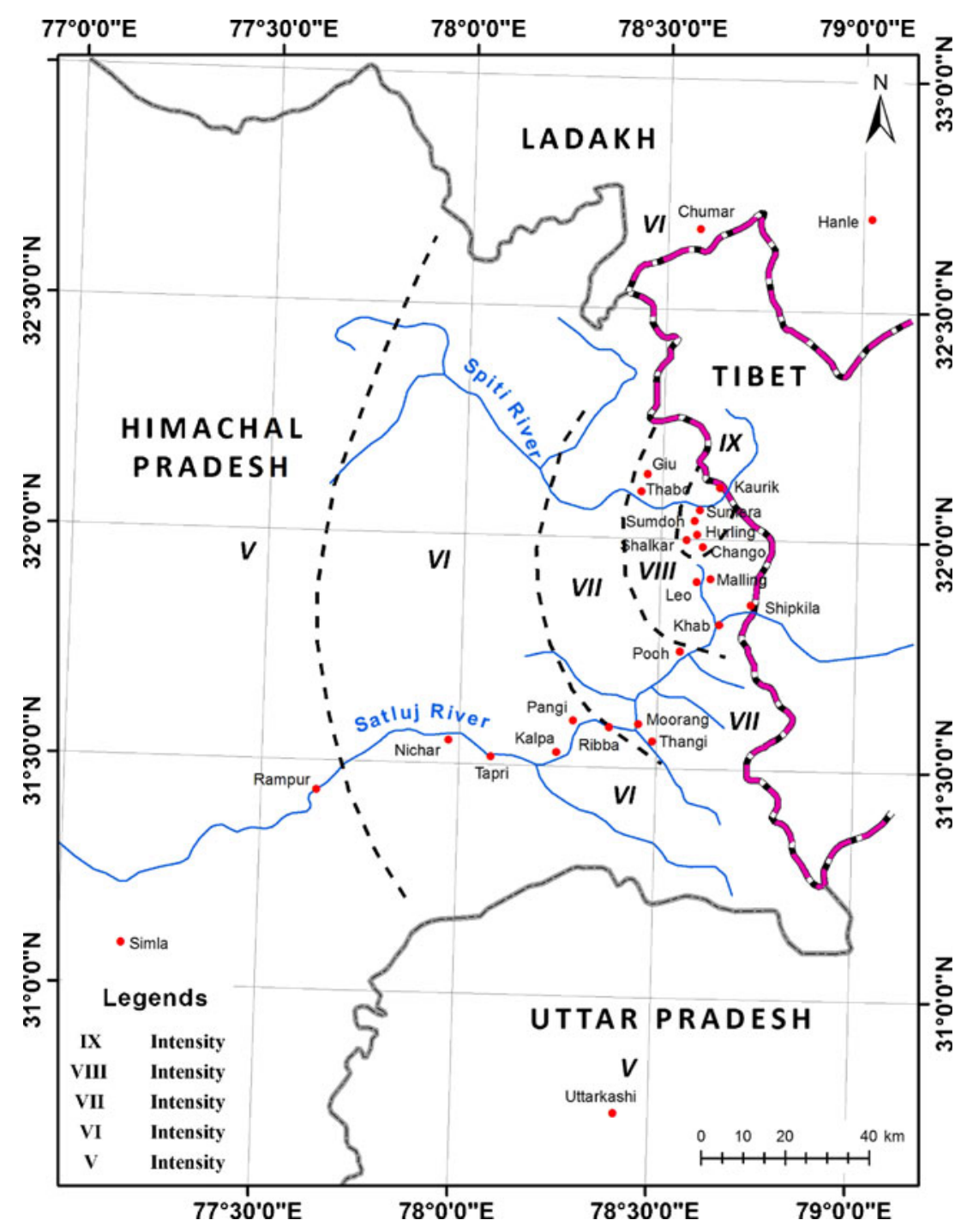

Figure 2(c). Isoseismal map of 1975 Kinnaur earthquake. The isoseismal maps have circular pattern and $17.0 \mathrm{~km}^{2}$ has been measured for intensity X.

same region at present, there would be a loss of 80,000 lives even if the earthquake strikes during daytime. This forecast has been verified to some extent by a causality figure of 86,000 during Muzaffarabad earthquake (2005, Mw 7.6). The four-times increase in number of fatalities of the 2005 event as compared to the 1905 earthquake is mainly due to several times increase in population and 'haphazard' construction of the dwellings and infrastructure without any consideration to seismic amplification. In addition to the great earthquakes, northwest Himalaya has also suffered several other major and moderate earthquakes with magnitude $>5$ to $<7$. These earthquakes are Central Himalaya (1505), Kumaon (1720), Satluj (1751), Garhwal-Mathura (1803, Mahajan et al. 2010). Recently, the magnitude of the Kangra earthquake (1905) has been revised to $M w 7.8$ (Ambraseys and Bilham 2000; Ambraseys and Douglas 2004).
It implies that the area is still capable of generating a great earthquake as it may not have released its energy that has been accumulated due to continuous northward convergence. Among the several moderate earthquakes of magnitude $>6$ and $<7$, the notable ones are Chamba (1945), Kinnaur (1975), Uttar Kashi (1991) and Chamoli (1999); earthquakes whose isoseismal data could be retrieved from literature for analysis (Iyengar and Sharma 1999; Pennington 1979; Kumar and Mahajan 1993; Mahajan and Virdi 2001).

\section{Procedure and data preparation}

To derive attenuation relation for northwest Himalayan region, intensity distribution maps of Kangra (1905), Chamba-1 (1945), Chamba-2 (1995), Kinnaur (1975), Dharamsala (1986), Uttar 
Kashi (1991), Garhwal-1 (1996), Garhwal-2 (1996), Sundarnagar (1997) and Chamoli (1999), have been used (Middlemiss 1910; Kaila and Sarkar 1978; Kumar and Mahajan 1990; Khattri 1992; Kumar and Mahajan 1993; Mahajan 1997, 1998; Mahajan and Virdi 2001). Methodology given by Anderson (1978) for intensity attenuation with distance has been used for each intensity level to compute attenuation characteristics. It can be correlated with the output which is a probability function and can be expressed as:

$$
\text { Probability }\left\{I<I_{1} / I_{0}, R\right\} \text {, }
$$

where the term $R$ is the epicentral distance, $I_{0}$ is the intensity at $R=0$ and $I_{1}$ is the selected intensity at a distance; intensity $I_{1}<$ intensity $I_{0}$ in the equation ( $I_{0}$ is the intensity at zero distance). During this study, a regression attenuation curve has been derived using statistical analysis. Data has been generated using the isoseismal map to derive the regression equation which has been provided either in R-F scale or MedevedevSponheuer-Karnik (MSK) scale, but initially transformed to the common scale.

\section{Methodology}

The locations of different earthquakes that have been used to derive the regression analysis are shown in figure 1. Isoseismal maps of these earthquakes which have been used in the study area are shown in figure $2(\mathrm{a}-\mathrm{j})$. Anderson (1978) technique

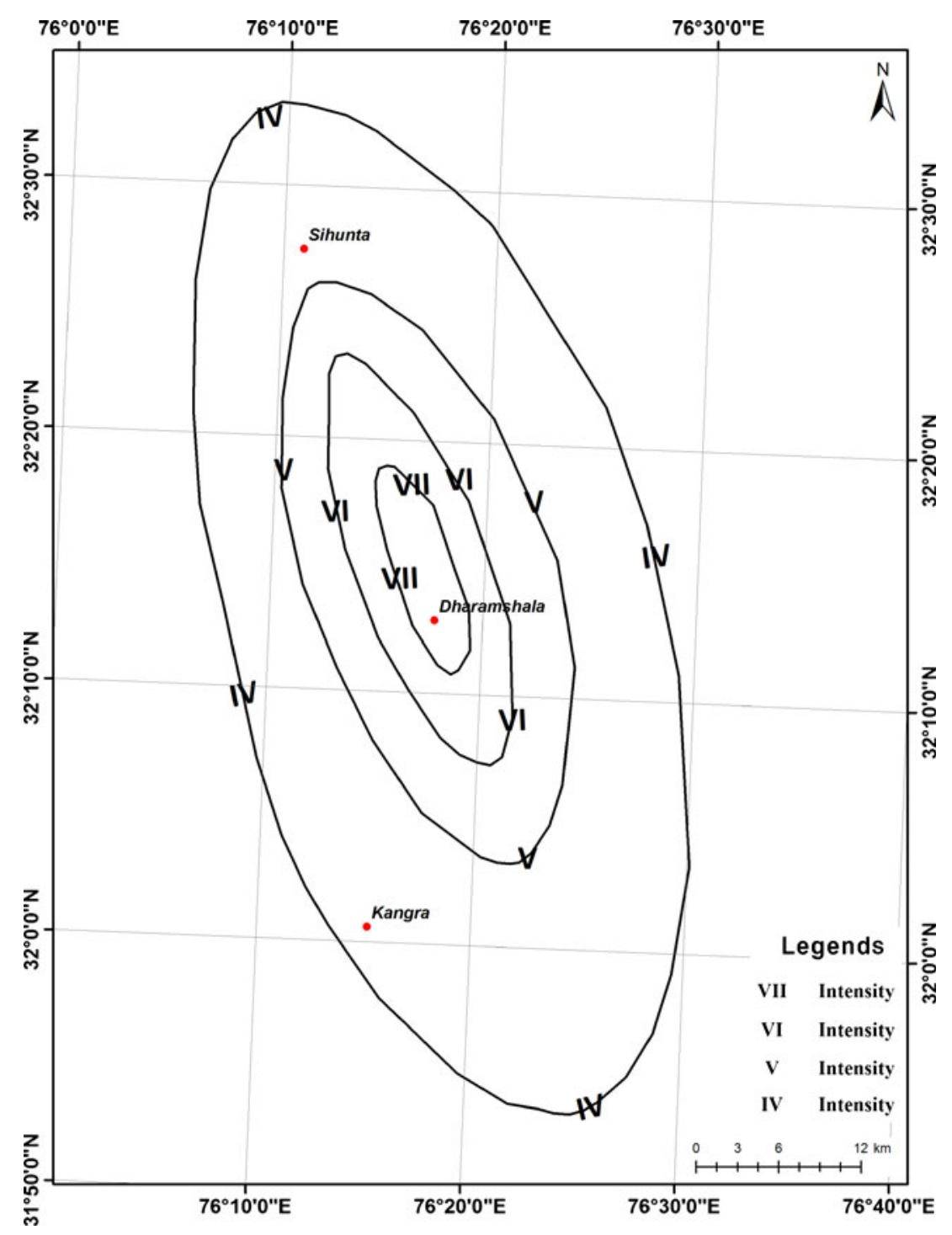

Figure 2(d). Isoseismal map of 1986 Dharmasala earthquake. The damaged pattern are in the NW-SE trend along the fault which was responsible for this earthquake. The maximum intensity was reported as VI, covering $43.0 \mathrm{~km}^{2}$. 
has been used to derive the epicentral distance versus intensity. The isoseismal map is divided into 16 radii from the epicentral point (refer figure 3). GIS software (Ilwis 3.1 GIS software 2002) has been used to calculate and generate digital data for further use. The intensity contours (X, IX, VIII, VII) are found to be closed in most of the isoseismal maps; they enable us to calculate the radii in different directions for regression analysis. However, in some cases, it is found that the outermost intensity contours were not found closed; which could be due to the non-availability of data or inaccessibility at that time of the survey. In that case, we inferred the contour line based on trends in rest of the contours and used the methodology given by Anderson (1978) for such cases to carry out analysis.

\section{Magnitude-intensity relation}

To derive an empirical intensity-magnitude relationship, the following regression equation has been used in the northwest Himalayan part of India.

$I_{0}=1.0442+1.1313 * M s \pm \sigma I \quad(\sigma I= \pm 0.8208)$,

where $I_{0}$ is the maximum intensity, $M s$ is the surface wave magnitude and $\sigma I$ is the root mean square (rms) error. The regression equation is generated as in equation (2). The plot between intensity and magnitude is shown in figure 4 . The circles indicate the earthquake's magnitude $(M s)$ with intensity $(I)$.

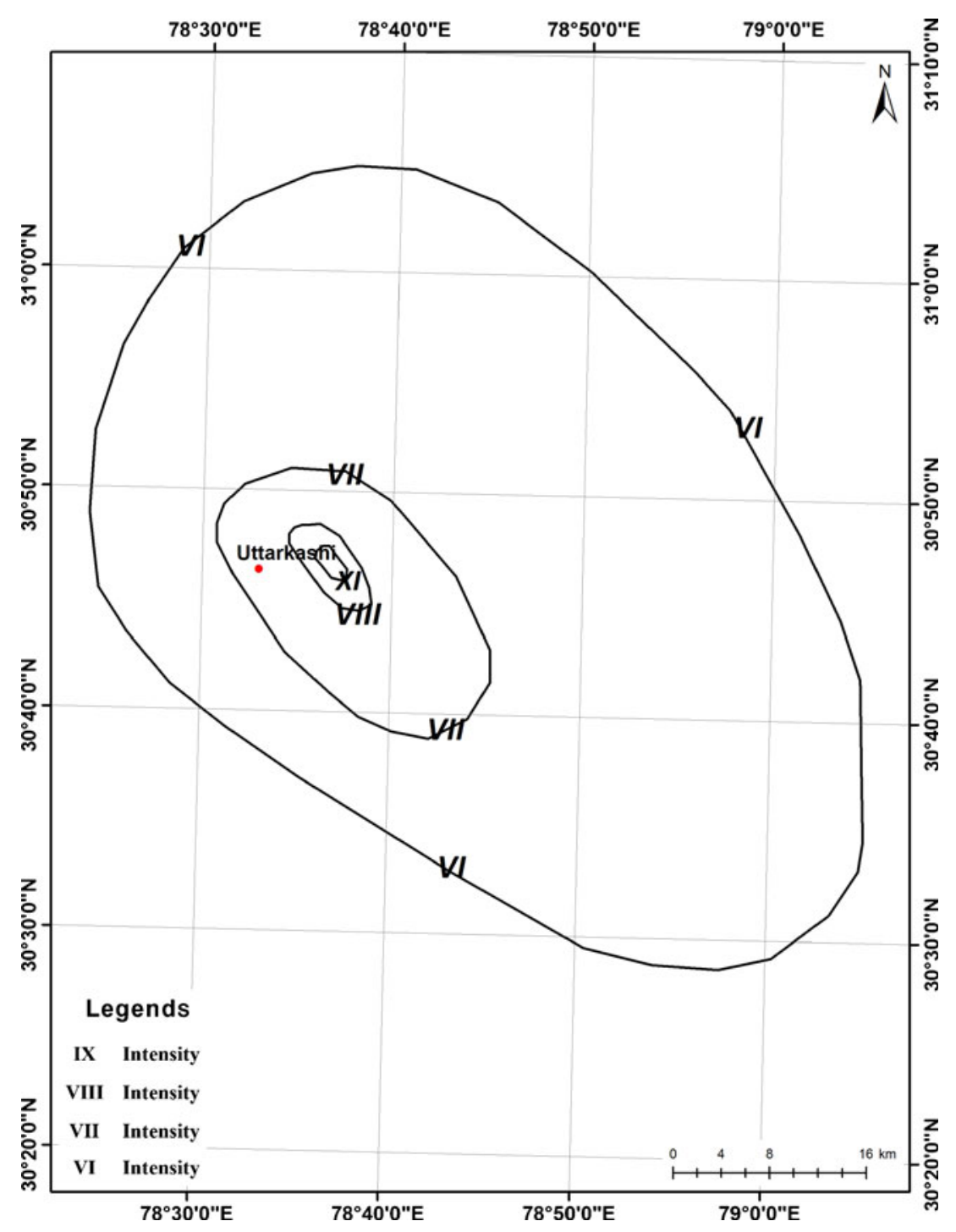

Figure 2(e). Isoseismal map of 1991 Uttar Kashi earthquake shows the fast attenuation pattern of seismic energy in the S-W part compared to the N-E part. The maximum intensity was reported as IX, covering $53.0 \mathrm{~km}^{2}$. 


\section{Intensity attenuation relation and regression analysis}

Regression analysis (using least square method) was performed on the evaluated set of data generated from the isoseismal maps of different earthquakes (table 1). It has been noted that $I_{0}$ value is an important factor to derive the standard equation. $I_{0}$ can be derived using the graphical method (Chandra et al. 1979) as well as computational techniques (Gutenberg and Richter 1956). In graphical methods, the graph has been plotted between intensity and epicentral distance with the help of isoseismal maps. As $I_{0}$ is very sensitive and represents maximum intensity of the miezoseismal zone, the epicentral distance is considered as zero. Finally, using Gutenberg and Richter (1956) relation, $I_{0}$ can be plotted. After substituting the
$I_{0}$ value in equation (2), intensity attenuation relation was derived. The graphical method has been used to calculate $I_{0}$; and by using least square fitting, $I_{0}=10.20889$ has been calculated. A generalized equation for the attenuation relation is shown below:

$$
I\left(R, I_{0}\right)=I_{0}+a+b R+c \operatorname{Ln}(R) \pm \sigma(I),
$$

where $I(R)=$ Intensity at epicentral distance $R$, $R=$ Epicentral distance $(\mathrm{km}), I_{0}=$ Intensity at epicentral distance zero $(\mathrm{km})$, and $a, b$ and $c=$ regression constants need to be calculated.

After regression analysis, the parameters calculated are $I_{0}=10.20889, a=0.43968, b=$ $-0.00017, c=-0.80248$.

$$
\sigma(I)= \pm 2.459146 \mathrm{e}-10 \text { (rms error) }
$$

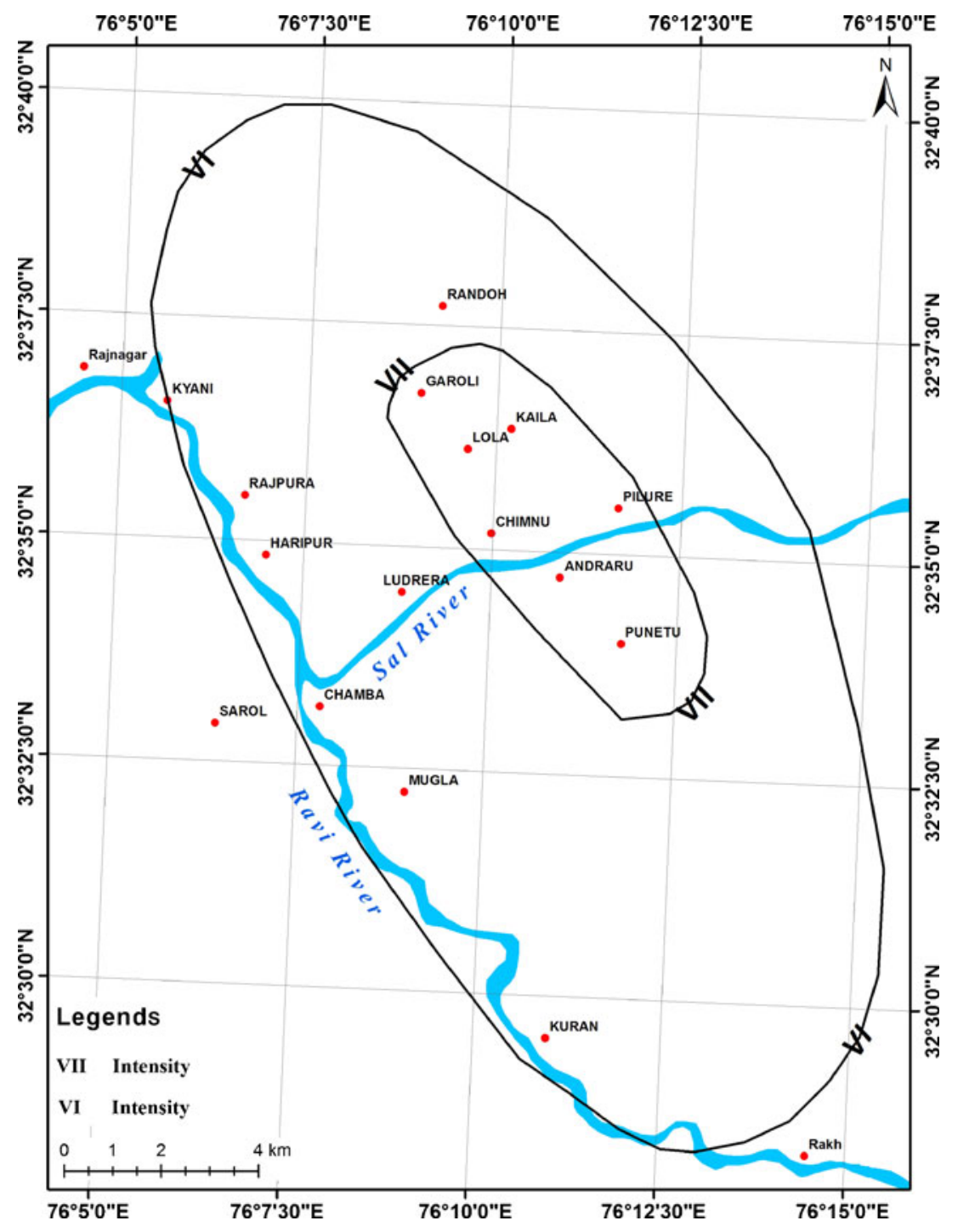

Figure 2(f). Isoseismal map of 1995 Chamba earthquake. Fast attenuation recorded at NE-SW direction compared to the NW-SE direction. The maximum intensity was reported as VII and covers $15.0 \mathrm{~km}^{2}$. 


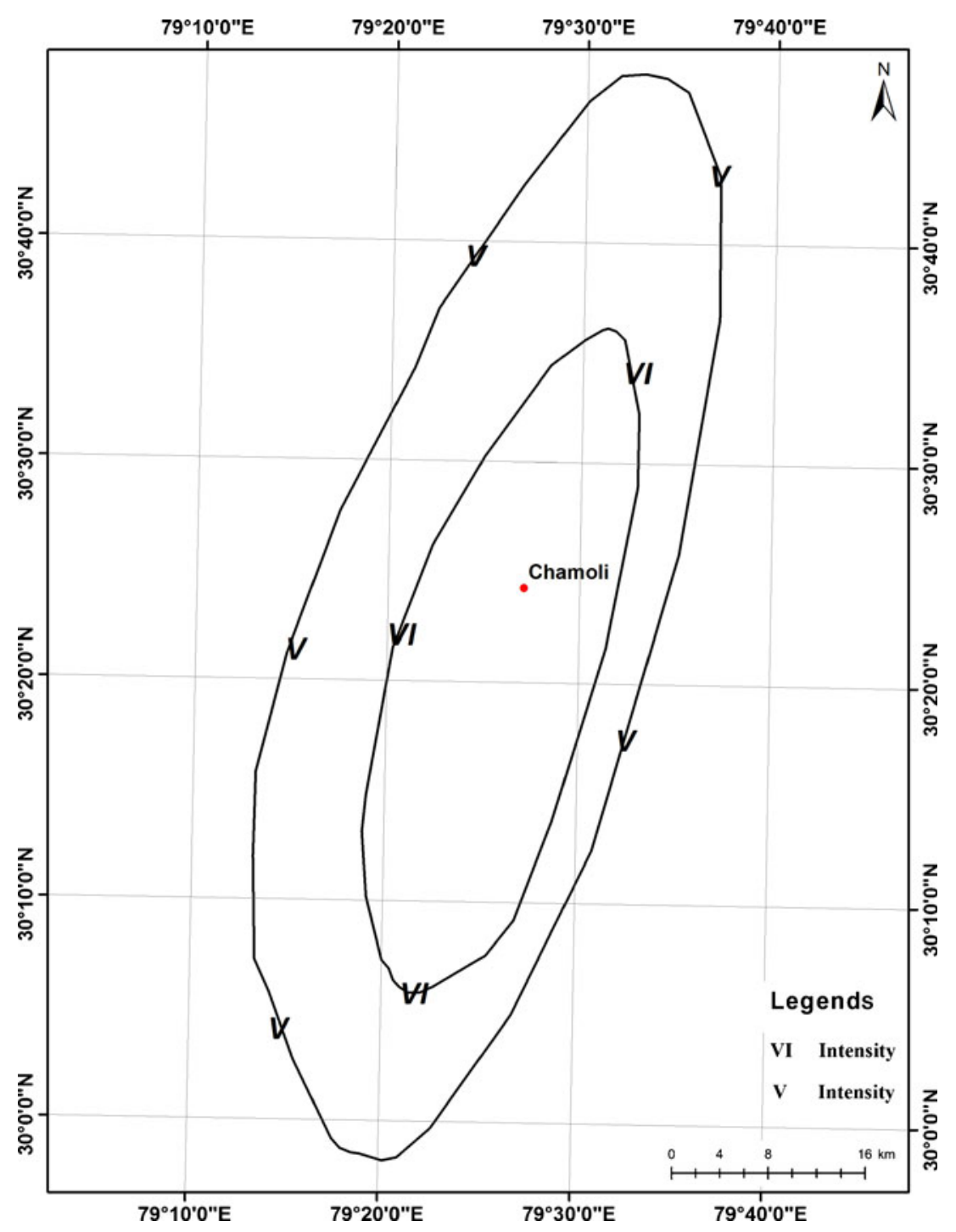

Figure 2(g). Isoseismal map of 1996 Garhwal-1 earthquake. The maximum intensity was reported as VI, covering $489.0 \mathrm{~km}^{2}$. The fast attenuation recorded NW-SE direction and comparatively less in NE-SW direction.

Replacing the values of all parameters in equation (3), we get equation (4).

$$
\begin{aligned}
I(R)= & 10.20889+0.43968-0.00017 * R \\
& -0.80248 * \operatorname{Ln}(R) \pm \sigma(I) .
\end{aligned}
$$

Using equations (2) and (4), the generalized equation can also be written in terms of intensity, magnitude and epicentral distance as:

$$
I=a+b M s+c R+d \operatorname{Ln}(R)
$$

After substituting the regression constants in equation (5), we derived the final equation in the form of equation (6):

$$
\begin{aligned}
I(R, M s)= & 1.4838-1.1313 * M s-0.00017 * R \\
& -0.80248 * \operatorname{Ln}(R) \pm \sigma(I) .
\end{aligned}
$$

Equation (6) can calculate empirically isoseismal intensity in the northwest Himalayan region using magnitude and epicentral distance. The term $c R$ and $d \operatorname{Ln}(R)$ terms in equation (5) are generally used to reflect intrinsic attenuation and geometrical spreading, respectively, although it is quite difficult to calculate these two terms.

\section{Earthquakes and isoseismal maps}

\subsection{Kangra earthquake (1905)}

The macroseismic locations of the region covered by the Kangra earthquake were assessed by Middlemiss (1910). He extends the isoseismal contours to the limit of perception of the earthquake (an area of more than 3.8 million $\mathrm{km}^{2}$ ) and includes a listing of the macroseismic aftershocks. These 


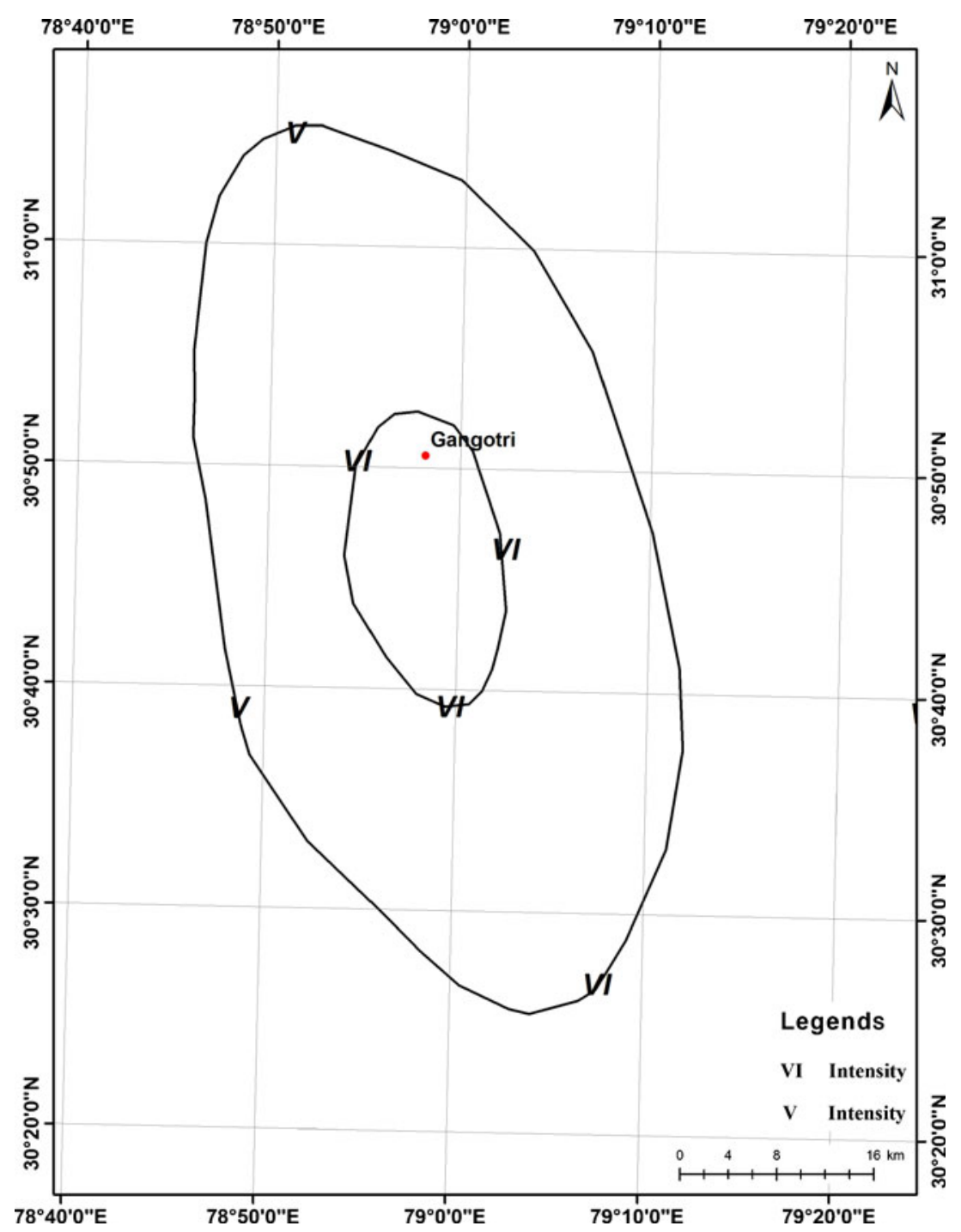

Figure 2(h). Isoseismal map of 1996 Garhwal-2 earthquake. The maximum intensity VI covered an area of $217.0 \mathrm{~km}{ }^{2}$. Fast attenuation is reported in the $\mathrm{E}-\mathrm{W}$ direction compared to the $\mathrm{N}-\mathrm{S}$ direction.

isoseismals are shown in figure 2(a). The damage was widespread, but heterogeneous, and if the isoseismals of Middlemiss (1910) accurately portray the strength of the ground motion, then the area covered by higher isoseismal, i.e., up to intensity VII is of great interest. The first aspect is that the majority of the affected area lies, south of the Main Boundary Thrust (MBT) in the Tertiary belt, which mainly represents highly fragile and weakened rocks known as sandstones interbedded with clay stones and mud stones. Secondly, the major tectonic features, i.e., MBT and its imbrications run parallel to the trend of the isoseismal pattern. The recent study of seismicity and its spatio-temporal variation (Kumar and Mahajan 2001) indicates that the region is still the centre of relatively high seismic activity. Observations of coda wave attenuation (Kumar et al. 2005) for the northwest Himalaya also indicate that the upper lithosphere around Kangra earthquake is highly tectonic and seismically active. The current sense of motion determined from the fault plane solution of the Dharamsala earthquake (1986) is the indication of thrust faulting on a southwest dipping plane striking northwest-southeast. The Kangra earthquake was also part of the same recognized tectonic trend. The destruction covered a vast area, but the isoseismics were reported to be elongated in the southeast direction and narrowed in the northeast and the northwest directions. The fast attenuation pattern of seismic energy in the north-western part as compared to south-eastern during Kangra earthquake direction motivated the study on attenuation characteristics of the region, mainly the regions covered by intensity VII and more.

Intensity attenuation with variable magnitudes at different epicentral distances has been derived 


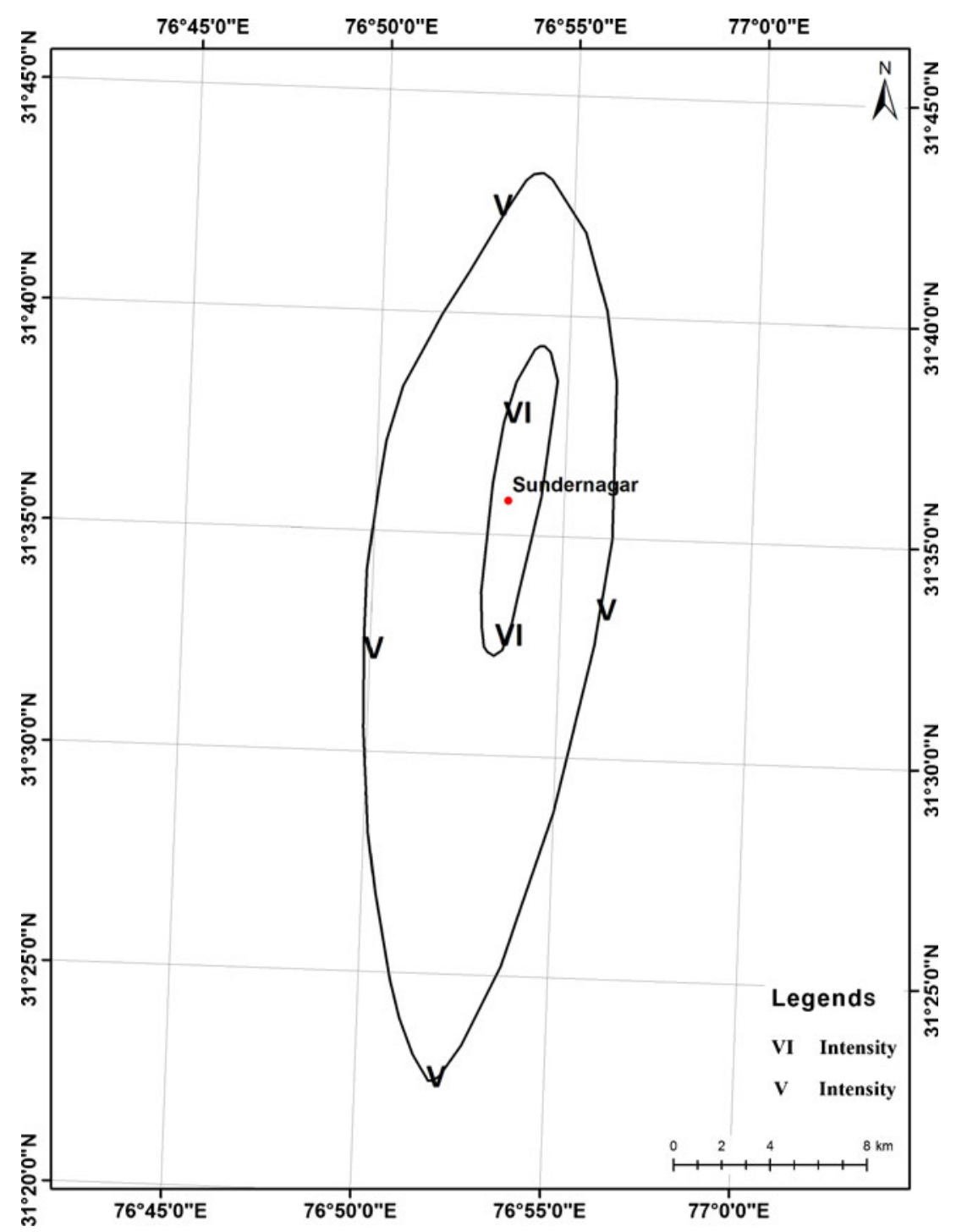

Figure 2(i). Isoseismal map of 1997 Sundarnagar earthquake. The maximum intensity VI was reported $8.0 \mathrm{~km}^{2}$. Fast attenuation is reported in the $\mathrm{E}-\mathrm{W}$ direction compared to the $\mathrm{N}-\mathrm{S}$ direction.

by Ghosh and Mahajan (2011) for the Kangra region, northwest Himalaya as:

$$
\begin{aligned}
I(R, M s)= & 2.856+1.31 * M s-0.0017 * R \\
& -0.9598 * \ln (R) .
\end{aligned}
$$

The given attenuation relation (7) is compared with the existing relations of seismic intensity, which shows that the attenuation curve for the northern Sonara (Mexico) region is similar to that of the Kangra region. It has also been inferred that the miezoseismal intensity at $R=0$ is very high at northern Sonara, Iran and Greece as compared to the Kangra region. Peak Ground Acceleration (PGA) has been used by the formula provided by Atkinson and Sonley (2000) by decreasing intensity with epicentral distance. The results show similar good agreement for the Kangra earthquake $(M w=8.4)$.

\subsection{Chamba-1 earthquake (1945)}

The zone of maximum intensity 10 (MMS) was located at the Kistwar window. Intensity zone was calculated for $296,568 \mathrm{~km}^{2}$ in an area having $192.08 \mathrm{~km}^{2}$ with maximum intensity IX, $7996 \mathrm{~km}^{2}$ with intensity VIII and $32757 \mathrm{~km}^{2}$ with intensity VII (Srivastava et al. 1987). The isoseismal map of Chamba earthquake (1945) is shown in figure 2(b).

\subsection{Kinnaur earthquake (1975)}

Earthquake occured at an altitude of $3000 \mathrm{~m}$ above the mean sea level of Himachal-Himalaya. Landslides, rock fall, snow avalanche occurred during this earthquake. An area of $17 \mathrm{~km}^{2}$ has been measured for intensity $\mathrm{X}, 746 \mathrm{~km}^{2}$ for intensity IX, $3076 \mathrm{~km}^{2}$ for intensity VIII, $7731 \mathrm{~km}^{2}$ for intensity VII and $25306 \mathrm{~km}^{2}$ for intensity VI, respectively 


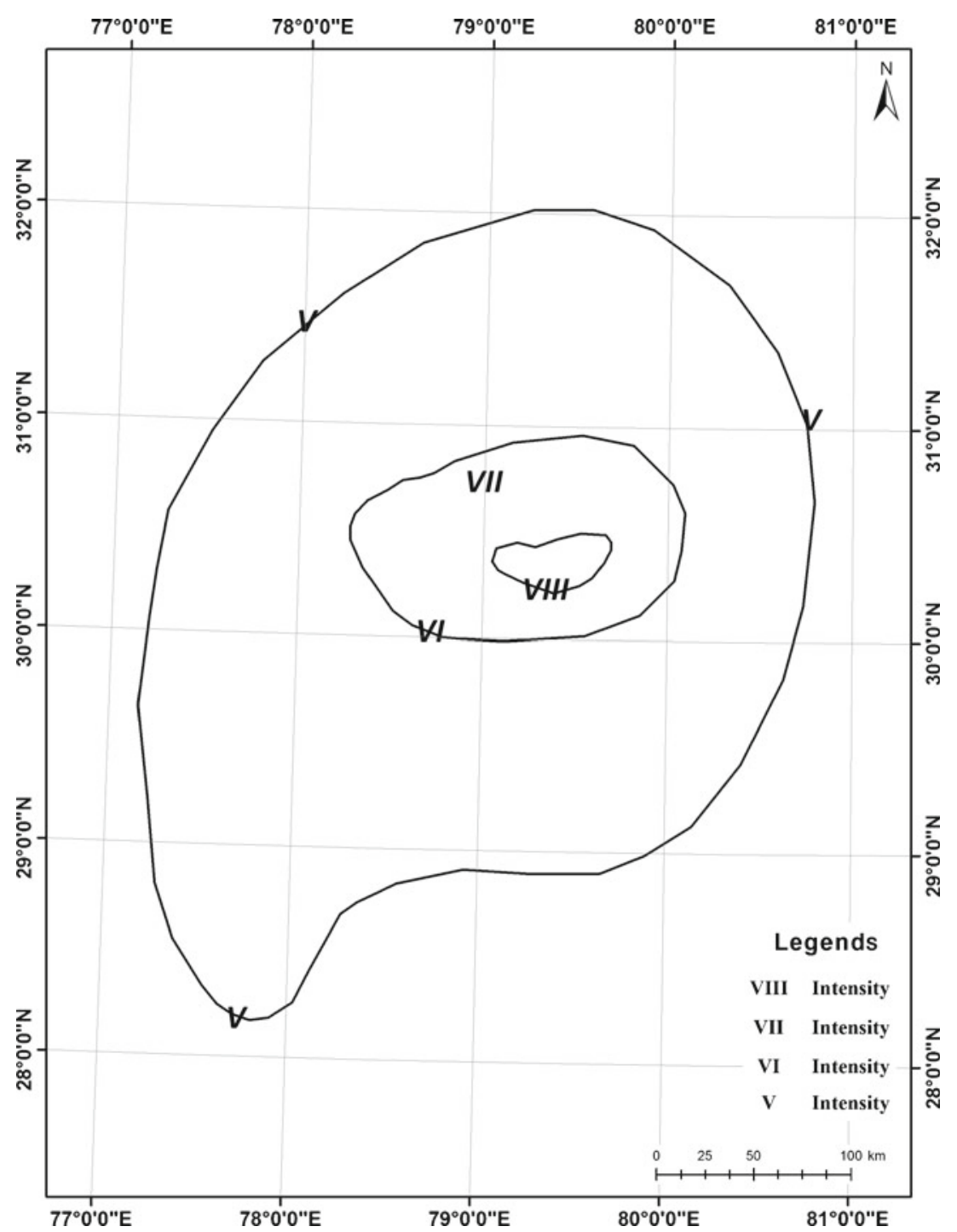

Figure 2(j). Isoseismal map of 1999 Chamoli earthquake. The maximum intensity was reported as VII, covering an area of $1800 \mathrm{~km}^{2}$. Attenuation of energy in the N-S direction was higher compared to the S-W direction.

(Singh et al. 1976). The isoseismal map of Kinnaur earthquake (1975) is shown in figure 2(c).

\subsection{Dharamsala earthquake (1986)}

There was widespread damage in Dharamsala town trending NW-SE fault which was responsible for this earthquake. An area of $7 \mathrm{~km}^{2}$ has been calculated for intensity zone VI and $43 \mathrm{~km}^{2}$ for intensity V (Kumar and Mahajan 1990, 1991). The isoseismal map of Dharamsala earthquake (1986) is shown in figure 2(d). The fault plane solution of this earthquake shows south dipping thrust which is in conformity with modelling given by Sriram and Khattri (1999) using strong motion data. The modelled expected peak ground accelerations for Dharamsala and Kangra for this hypothetical event are 0.7 and $0.5 \mathrm{~g}$, respectively compared to 0.2 and $0.15 \mathrm{~g}$ recorded for the mb 5.7 Dharamsala earthquakes. The recorded values are in conformity with the high intensity values of the earthquake (Sriram and Khattri 1999).

\subsection{Uttar Kashi earthquake (1991)}

This earthquake affected a large population, disrupted communication and caused striking terrain changes. Intensity IX area was calculated as $53 \mathrm{~km}^{2}$. However, intensity VIII was calculated for $365 \mathrm{~km}^{2}$ by GSI (2001) and later after Narula et al. (1995), it was calculated as $441 \mathrm{~km}^{2}$. The isoseismal map of Uttar Kashi earthquake (1991) is shown in figure $2(\mathrm{e})$.

\subsection{Chamba earthquake-2 (1995)}

There were many damages recorded in the town of Chamba. Maximum intensity VII covers an area of 


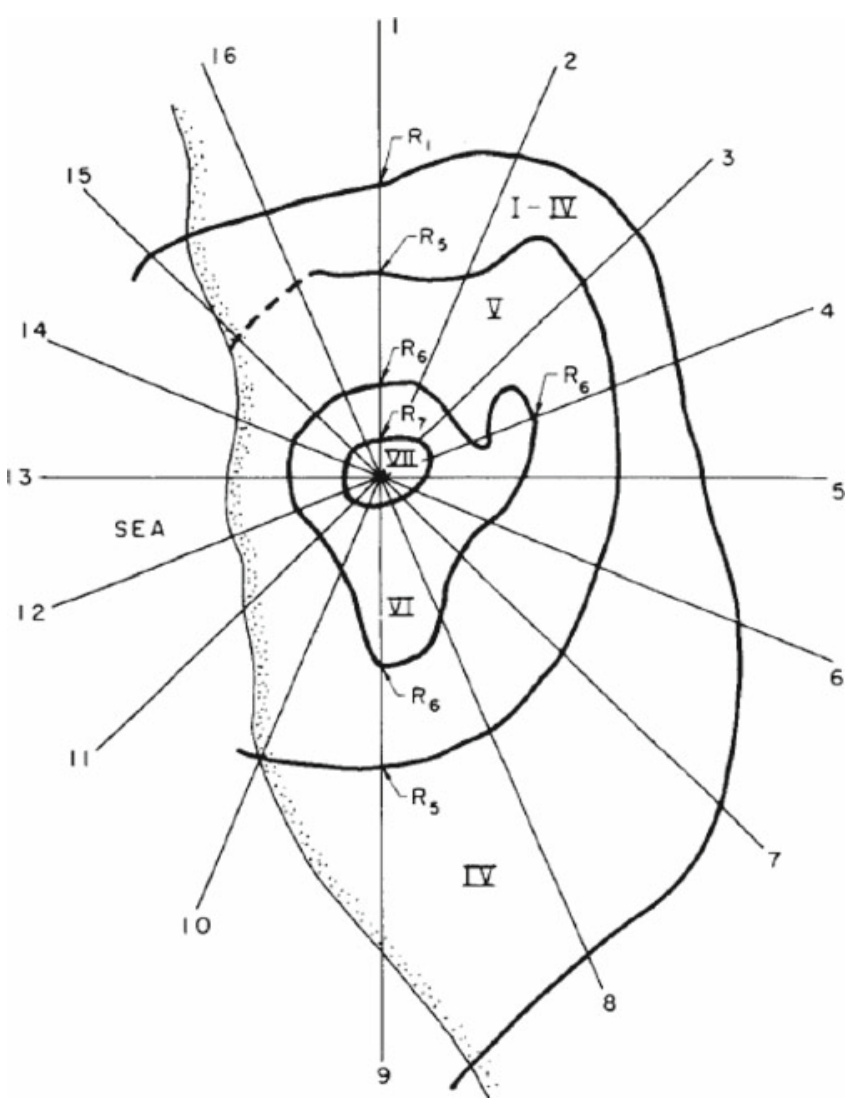

Figure 3. Example of isoseismal map showing the convention used to measure 16 radii from I1 to I16 (after Anderson 1978).

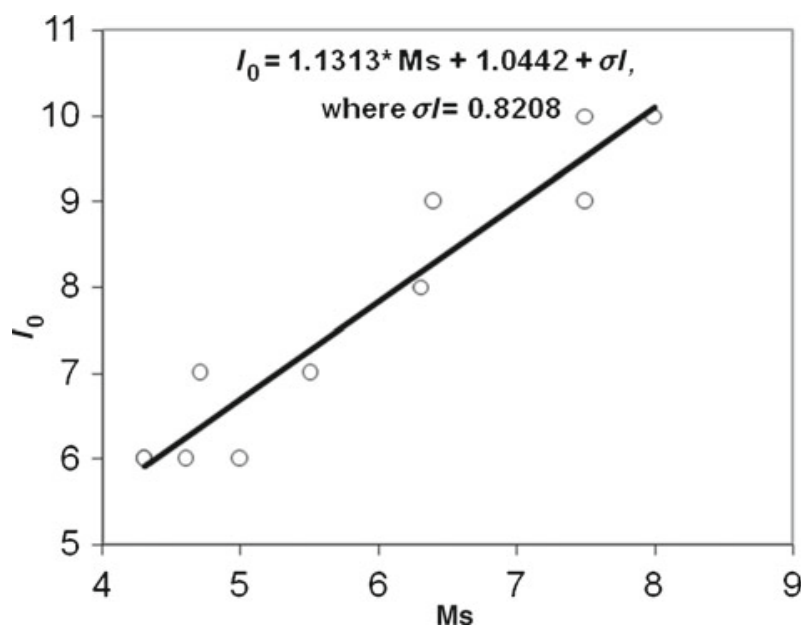

Figure 4. Intensity magnitude relation derived from least square regression analysis.

$15 \mathrm{~km}^{2}$. The average region is a part of the seismically active Kangra Chamba zone. This earthquake was correlated with the local faults present in the area trending NW-SE direction (Mahajan 1998). The isoseismal map of Chamba earthquake (1995) is shown in figure $2(\mathrm{f})$.
7.7 Garhwal earthquake-1 (1996)

Garhwal experienced two major distance earthquakes between Uttar Kashi (1991) and Chamoli (1999) earthquakes. Maximum intensity was VI, reported by Geological Survey of India (GSI 2001). An area of $489 \mathrm{~km}^{2}$ was covered by intensity VI. The isoseismal map of Garhwal earthquake (1996) is shown in figure $2(\mathrm{~g})$.

\subsection{Garhwal earthquake-2 (1996)}

The maximum intensity VI covered an area of $217 \mathrm{~km}^{2}$ (GSI 2001). The isoseismal map of Garhwal earthquake (1996) is shown in figure 2(h).

\subsection{Sundarnagar earthquake (1997)}

The maximum intensity VI covered an area of $8 \mathrm{~km}^{2}$ (Mahajan 1997, 1998). The area lies in seismic zone $\mathrm{V}$ and is currently active due to the neotectonic activity and Sundarnagar fault which is located inbetween MBT and Main Central Thrust (MCT). The isoseismal map of Sundarnagar earthquake (1997) is shown in figure 2(i).

\subsection{Chamoli earthquake (1999)}

The maximum intensity was reported as VII in MSK scale. Intensity VII covered an area of $1800 \mathrm{~km}^{2}$ in east-west direction causing 103 deaths, 395 injured and much damage to more than 4500 homes and numerous landslides. Reactivation of old landslides, development of cracks in roads and ground fissures, drying up of existing springs and emergence of new springs are reported in the area of isoseismal VII. In isoseismal VIII, the town chamber suffered heavy damage, collapse of walls of mud houses and brick buildings (Mahajan and Virdi 2001; Rastogi 2000; Kayal et al. 2003). The isoseismal map of Chamoli earthquake (1999) is shown in figure $2(\mathrm{j})$.

Figure 4 shows the attenuation pattern of the different earthquakes which occurred in the northwest Himalayan region and the decay rate can explain the attenuation pattern of the particular earthquake. The attenuation pattern of Dharamsala earthquake is much higher than the other earthquakes; however the attenuation of intensity in Kinnaur earthquake is comparatively lower. The different intensity attenuation curves are shown in figure 5. Using data from all the earthquakes, the empirical intensity attenuation equation is generated for the northwest Himalayan region (refer to figure 6). Since very scanty data of strong motion data is available, effort has been made to derive the attenuation relation from intensity 
Table 1. Details of significant earthquakes of northwest Himalayan region (Ms $\geq 4.3$ ), essentially reproduced from various catalogues.

\begin{tabular}{|c|c|c|c|c|c|c|c|}
\hline \multirow[b]{2}{*}{ Sl. no } & \multirow[b]{2}{*}{ Date } & \multirow[b]{2}{*}{ Place } & \multicolumn{2}{|c|}{ Locations } & \multirow[b]{2}{*}{ Intensity } & \multicolumn{2}{|c|}{ Magnitude } \\
\hline & & & Lat. ${ }^{\circ} \mathrm{N}$ & Long. ${ }^{\circ} \mathrm{E}$ & & $(\mathrm{Ms})$ & References \\
\hline 1 & 04.04 .1905 & Kangra & 32.30 & 76.25 & 10.0 & 7.8 & Ambraseys and Bilham (2000) \\
\hline 2 & 22.06 .1945 & Chamba-1 & 32.60 & 75.90 & 9.0 & 7.5 & Srivastava et al. (1987) \\
\hline 3 & 19.01.1975 & Kinnaur & 32.38 & 78.49 & 9.0 & 7.5 & Singh et al. (1976) \\
\hline 4 & 26.04 .1986 & Dharmashala & 32.15 & 76.40 & 6.0 & 5.0 & Kumar and Mahajan (1990) \\
\hline 5 & 20.10 .1991 & Uttar Kashi & 30.76 & 76.79 & 9.0 & 6.4 & Narula et al. (1995) \\
\hline 6 & 24.03.1995 & Chamba-2 & 32.66 & 76.16 & 7.0 & 4.9 & Mahajan $(1997,1998)$ \\
\hline 7 & 23.01.1996 & Garhwal-1 & 30.46 & 79.41 & 6.0 & 4.3 & GSI Report (2001) \\
\hline 8 & 26.03.1996 & Garhwal-2 & 30.69 & 79.10 & 6.0 & 4.6 & GSI Report (2001) \\
\hline 9 & 29.07.1997 & Sundarnagar & 31.56 & 76.86 & 6.0 & 4.3 & Mahajan $(1997,1998)$ \\
\hline 10 & 28.03.1999 & Chamoli & 30.51 & 79.42 & 8.0 & 6.3 & $\begin{array}{l}\text { Mahajan and Virdi (2001); } \\
\text { Kayal et al. (2003); } \\
\text { and Rastogi (2000) }\end{array}$ \\
\hline
\end{tabular}

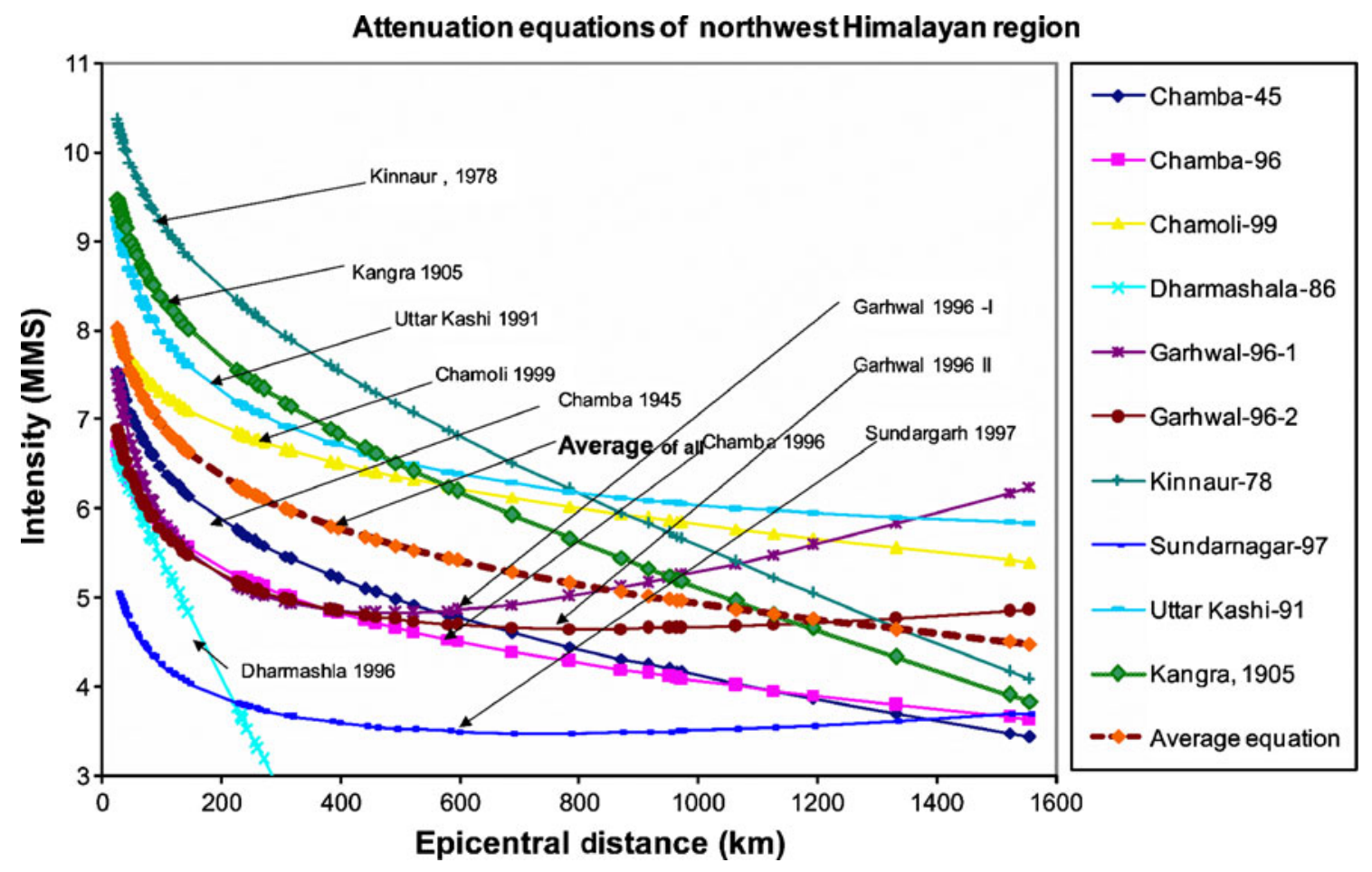

Figure 5. Attenuation pattern of various earthquakes of the northwest Himalayan region.

attenuation, which will more or less reflect the effect of earthquake excitation on surface geology and soil.

\section{Seismic hazard implementation}

The seismicity map of northwest Himalaya provides information on the activity rate and possible indications for future seismic activity in the form of seismic precursors, whereas the intensity maps provide information on the impact of earthquake on society and built environment, and thus reflection site amplification. The site amplification varies from site to site which depends on the attenuation characteristics of the area. In the absence of strong motion data, computation of seismic hazard may not be feasible and the best alternative for assessing the seismic hazard of any area is to derive attenuation relations from the available data, i.e., isoseismal maps.

The attenuation relation given in equation (6) has been used for Kangra region which shows good agreement with the already established attenuation 


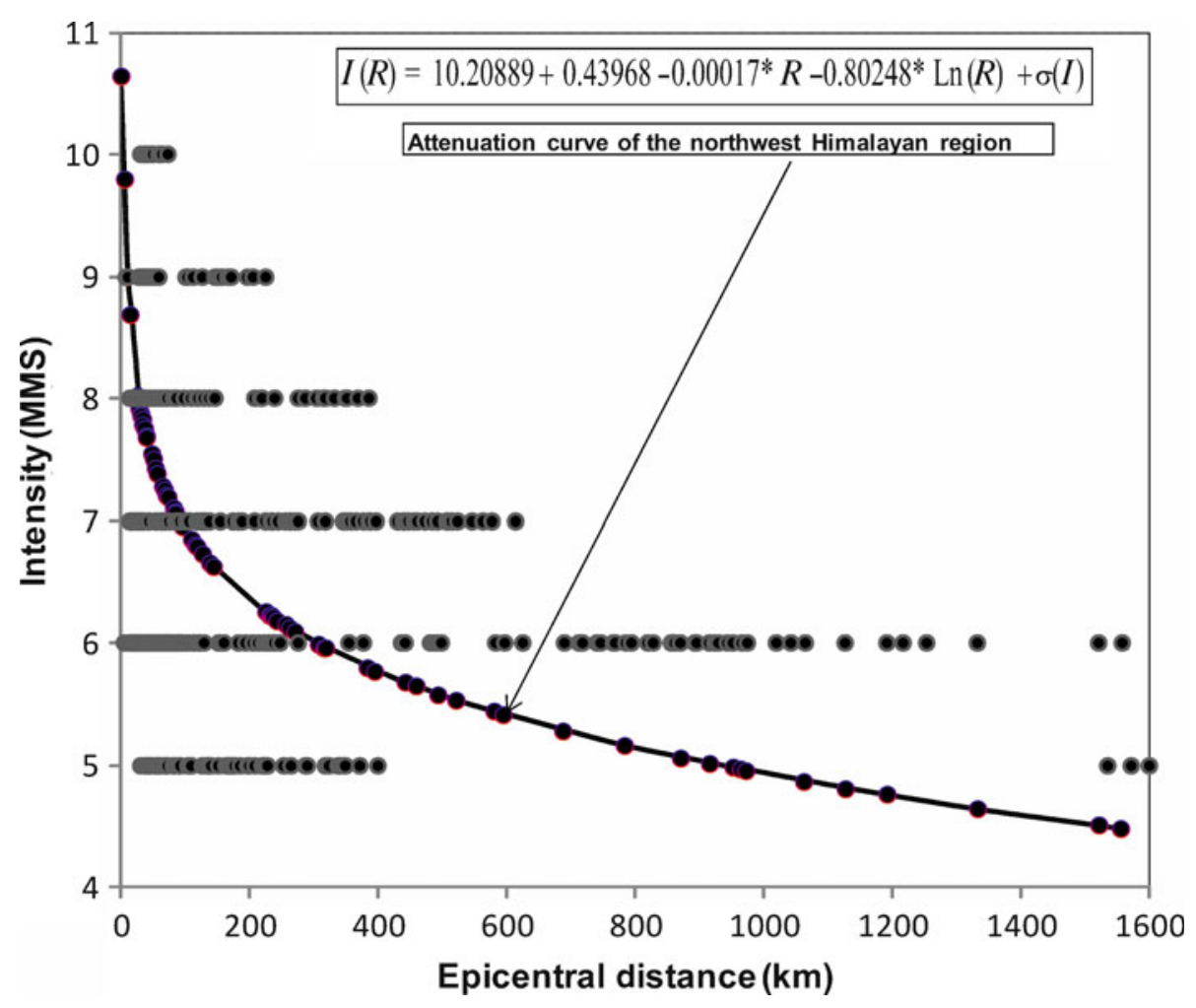

Figure 6. Attenuation relation of the northwest Himalayan region.

relation for the Kangra region derived by Kumar et al. (1997) from Dharamsala earthquake's (1986) strong motion data in different observatories at Kangra region. The attenuation relation derived by Kumar et al. (2005) with the help of coda wave attenuation for Kangra region of northwest Himalaya can be written as:

$$
A=A_{0} e^{-k x}
$$

where $k$ is the exponential decay factor equivalent to $\pi f / Q \beta$ with reference to a distance of $x$ in kilometre and $\beta$ represents the S-wave velocity (considered here as $3.5 \mathrm{~km} / \mathrm{s}$ ). The $\pi$ symbol is numerically equivalent to $3.1415, f$ is the frequency of the different media and $Q$ is quality factor at the reference frequency $f$. $A$ is amplitude (attenuation amplitude) and $A_{0}$ is the amplitude at $x=$ $0 \mathrm{~km}$ distance, i.e., $A=A_{0}$ in that case. The characteristics of the ground motion attenuation using these relations are plotted in figure 6 .

The attenuation of ground motion which results from the present intensity data looks more closer to Kumar et al. (1997) and is higher than that of Kumar et al. (2005) (refer to figure 6). This may be because coda wave attenuation obtained by Kumar et al. (2005) does not provide total attenuation characteristics. The attenuation relation obtained from the intensity data mostly reproduced the seismic hazard picture in a more pragmatic way since the effect of earthquakes that can qualify intensity scales were used to enumerate exact amplification values of the soil site.

\section{Conclusion}

The distribution of intensity of any site depends on the earthquake source, propagation path between the source and receiver and near-surface material. Near-surface material may result in site amplification which is governed by site geology, topography, depth to water table and soil saturation. The different responses shown by man-made structures and people to ground motion define the intensity level. Hence, to mitigate the effects of earthquakes, it is very important to understand the behaviour of the seismic energy attenuation between the source and the site. The attenuation of intensity relation derived for northwest Himalaya region reflects the site-specific attenuation relation which will help in improving the seismic hazard assessment of the northwest Himalaya. The intensity maps of the northwestern earthquakes have been considered as a function of magnitude and epicentral distance, which can also be applicable for the seismic hazard assessment. The regression equations were generated with least square fitting using intensity 
with epicentral distance and intensity, epicentral distance and magnitude. Both the relations are given below:

$$
\begin{aligned}
I\left(R, I_{0}\right)= & I_{0}+0.43968-0.00017 * R \\
& -0.80248 * \operatorname{Ln}(R) \pm \sigma(I) \\
& \left(\text { where } I_{0}=10.20889\right)
\end{aligned}
$$

and

$$
\begin{aligned}
I(R, M s)= & 1.4838-1.1313 * M s-0.00017 * R \\
& -0.80248 * \operatorname{Ln}(R) \pm \sigma(I) \\
& (\text { where } \sigma(I)= \pm 2.459146 \mathrm{e}-10),
\end{aligned}
$$

where $R$ is the epicentral distance in kilometres, $I(R)$ is intensity with respect to epicentral distance, $M s$ is the surface wave magnitude and $\sigma I$ is the rms error. The empirical relations derived from intensity attenuations are well-correlated with the relation obtained from few strong motion data in and around the epicentral zone. The use of the attenuation relation derived from the intensity data may reflect the seismic hazard assessment picture in a more realistic way because the intensity values represent the exact amplification values of the soil site.

\section{Acknowledgements}

The authors are thankful to many authors of various articles, directly or indirectly for their ideas and inspiration throughout the work. They also thank two anonymous reviewers for their constructive criticism. The authors gratefully acknowledge the editor for valuable comments and suggestions.

\section{References}

Ambraseys N N 1995 The prediction of earthquake peak ground acceleration in Europe; Earthq. Eng. Struct. Dyn. 24 467-490.

Ambraseys N N 2001 Reassessment of earthquakes, 19001999, in the Eastern Mediterranean and the Middle East; Geophys. J. Int. 145 471-485.

Ambraseys N and Bilham R 2000 A note on the Kangra $\mathrm{Ms}=7.8$ earthquake of 4 April, 1905; Curr. Sci. 79(1) $45-50$.

Ambraseys N N and Douglas J 2004 Magnitude calibration of north Indian earthquakes; Geophys. J. Int. 158 $1-42$.

Anderson J G 1978 On attenuation of modified Mercalli intensity with distance in the United States; Bull. Seismol. Soc. Am. 68 1147-1179.

Arya A S 1990 Damage scenario of a hypothetical 8.0 magnitude earthquake in Kangra Region of Himachal Pradesh; Bull. Indian Soc. Earthq. Technol., paper no. 297 27(3) 121-132.
Atkinson G M and Mereu R 1992 The shape of ground motion attenuation curves in southeastern Canada; Bull. Seismol. Soc. Am. 82 2014-2031.

Atkinson G M and Sonley E 2000 Empirical relationships between modified Mercalli intensity and response spectra; Bull. Seismol. Soc. Am. 90 537-544.

Bakun W H and McGarr A 2002 Differences in attenuation among the stable continental regions; Geophys. Res. Lett. 29(23) 2121, doi: 10.1029/2002GL015457.

Bakun W H and Wentworth C M 1999 Estimating earthquake location and magnitude from seismic intensity data; Bull. Seismol. Soc. Am. 87(6) 1502-1521.

Bindi D, Parolai S, Grosser H, Milkereit C and Karakisa S 2006 Crustal attenuation characteristics in north-western Turkey in the range from 1 to $10 \mathrm{~Hz}$; Bull. Seismol. Soc. Am. 96 200-214.

Bollinger G A 1977 Reinterpretation of intensity for the 1886 Charleton, South Carolina earthquake in studies related to the Charleston South Carolina earthquake of 1886) - A preliminary report. U.S. Geol. Surv. Professional Paper, 1028-B, 32

Böse M 2006 Earthquake early warning for Istanbul using artificial neural networks, Ph.D. Thesis, University of Karlsruhe, available at http://digbib.ubka.unikarlsruhe.de/volltexte/1000005845 181p.

Brazee R J 1976 Final report, An analysis of earthquake intensities with respect to attenuation, magnitude, and rate of recurrence; NOAA Technical Memorandum EDS, NGSDC-2, National Oceanic and Atmospheric Administration, Environmental Data Service, Boulder, CO, 98p.

Brazee R J 1979 Re-evaluation of modified Mercalli intensity scale for earthquakes using distance as determinant; Bull. Seismol. Soc. Am. 69 911-924.

Chandra U 1979 Attenuation of intensity in the United States; Bull. Seismol. Soc. Am. $692003-2024$.

Chandra U, McWhorter J G and Nowroozi A A 1979 Attenuation of intensity in Iran; Bull. Seismol. Soc. Am. 69(1) $237-250$.

Ghosh G K and Mahajan A K 2011 Interpretation of intensity attenuation relation in 1905 Kangra earthquake with epicentral distance and magnitude in the northwest Himalayan region; J. Geol. Soc. India 77 511-520.

GSI Report 2001 Seismotectonic Atlas of India, Geol Surv. India, Spec. Publ.

Gupta I N and Nuttli O W 1976 Spatial attenuation of intensities for central U.S. earthquakes; Bull. Seismol. Soc. Am. 66 743-751.

Gutenberg B and Richter C F 1956 Earthquake magnitude, intensity, energy and acceleration special paper; Bull. Seismol. Soc. Am. 46 105-145.

Howel B J Jr and Schultz T R 1975 Attenuation of modified Marcalli intensity with distance from the epicenter; Bull. Seismol. Soc. Am. 65 651-665.

Ilwis 3.12002 GIS and image processing software, ITC, Netherlands.

Iyengar R N and Sharma D 1999 Some earthquakes of the Himalayan region from historical sources; Him. Geol. 20(1) 81-85.

Kaila K L and Sarkar D 1978 Atlas of isoseismal maps of major earthquakes in India; Geophys. Res. Bull. 16 233-267.

Kayal J R, Sagina Ram, Singh O P, Chakraborty P K and Karunakar G 2003 Aftershocks of the March 1999 Chamoli Earthquake and seismotectonic structure of the Garhwal Himalaya; Bull. Seismol. Soc. Am. 93 109-117.

Khattri N K 1992 Seismic hazard in Indian region; Curr. Sci. 62(1 \& 2) 109-116. 
Kumar S and Mahajan A K 1990 Studies of intensities of 26th April, 1986 Dharamsala earthquake and associated tectonics; Geol. Soc. India 35 213-219.

Kumar S and Mahajan A K 1991 Dharmasahla seismotectonics zone, Neotectonic and state of stress in the area; J. Him. Geol. 21 53-57.

Kumar S and Mahajan A K 1993 The Uttar Kashi earthquake of 20th October, 1991: Field observations; Terra Nova 6(2) 95-99.

Kumar S and Mahajan A K 2001 Spatio temporal variation of seismicity in relation to fracture tectonic of Kangra region, Northwest Himalaya; Tectonophys. 331(4) 359371.

Kumar D, Teotia S S and Khattri K N 1997 The representability of attenuation characteristics of strong ground motions observed in 1986 Dharamsala and 1991 Uttar Kashi earthquakes by available empirical relations; Curr. Sci. 73 543-548.

Kumar N, Parvez I A and Virk H S 2005 Estimation of coda wave attenuation for NW Himalayan region using local earthquakes; Phys. Earth Planet. Interior 151 243-258.

Mahajan A K 1997 A report of 29th July 1997 Sundarnagar earthquake field observations and seismotectonics; Wadia Institute Report (internal).

Mahajan A K 1998 The 24th March, 1995 Chamba earthquake (NW Himalaya), field observations and seismotectonics; J. Geol. Soc. India 51 227-232.

Mahajan A K and Virdi N S 2001 Macroseismic field generated by the 29th March Chamoli Earthquake, 1999 and its seismotectonics; J. Asian Earth Sci. 19(4) 507-516.

Mahajan A K, Thakur V C, Sharma M L and Chauhan M 2010 Probabilistic seismic hazard map of NW Himalaya and its adjoining area, India; Nat. Hazards 53 443-457, doi: 10.1007/s11069-009-9439-3.

Miao Q and Langston C A 2008 Comparative study of distance attenuation in Central United States and Western India; Seismol. Res. Lett. 79(3) 446-456.

Middlemiss C S 1910 The Kangra earthquake of 4th April 1905; Geol. Surv. India Memoir 38.

Narula P L, Shome S K, Kumar S and Pandey P 1995 Damage pattern and delineation of isoseismals of Uttar Kashi earthquake of 20th October 1991; Geol. Soc. India Memoir 30 1-18.

Özbey C, Ali S, Lance M, Mustafa E and Yasin F 2004 An empirical attenuation relationship for north-western Turkey ground motion using a random effects approach; Soil Dyn. Earthq. Eng. 24 115-125.
Parolai S, Grosser H, Milkereit C and Karakisa S 2006 Crustal attenuation characteristics in northwestern Turkey in the range from 1 to $10 \mathrm{~Hz} ;$ Bull. Seismol. Soc. Am. 96(1) 200-214.

Pennington W D 1979 A summary of field and seismic observations of the Pattan earthquake: 28 December, 1974; In: Geodynamics of Pakistan (eds) Farah A and Delong K A, Geol. Surv. of Pakistan, Quetta, pp. 143-147.

Rastogi B K 2000 Chamoli earthquake of magnitude 6.6 on 29 March 1999; Geol. Soc. India 55 505-514.

Sbar L M and Dubois M S 1984 Attenuation of Intensity for the 1887 Northern Sonara, Mexico earthquake; Bull. Seismol. Soc. Am. 74(6) 2613-2628.

Singh S, Jain A K, Sinha P, Singh V N and Srivastava L S 1976 The Kinnaur earthquake of January 19, 1975: A field report; Bull. Seismol. Soc. Am. 66(3) 887-901.

Sokolov V Y 2002 Seismic intensity and Fourier acceleration spectra: Revised relationship; Earthq. Spectra 18 $161-187$.

Sørensen M B, Stromeyer D and Grünthal G 2009 Attenuation of macroseismic intensity: A new relation for the Marmara Sea Region, Northwest Turkey; Bull. Seismol. Soc. Am. 99(2A) 538-553.

Sriram V and Khattri K N 1999 Modelling of strong ground motions from Dharmsala earthquake of 1986 (mb 5.7); Curr. Sci. 76(3) 429-438.

Srivastava H N, Dube R K and Hansraj 1987 Space and time variation in seismicity patterns preceeding two earthquakes in the Himachal Pradesh, India; Tectonophys. 113 69-77.

Stromeyer D and Grünthal G 2009 Attenuation relationship of macroseismic intensities in central Europe; Bull. Seismol. Soc. Am. 99 554-565.

Szeliga W, Hough S, Martin S and Bilham R 2010 Intensity, magnitude, location, and attenuation in India for felt earthquakes since 1762; Bull. Seismol. Soc. Am. 100(2) 570-584.

Tilford N R, Chandra U, Amick D C, Moran R and Snider F 1985 Attenuation of intensities and effect of local site conditions observed intensities during the Corinth Greece earthquakes of 24 and 25 February and 4 March, 1981; Bull. Seismol. Soc. Am. 75(4) 923-937.

Zaré M and Memarian H 2003 Macroseismic intensity and attenuation laws: A study on the intensities of the Iranian earthquakes of 1975-2000; Fourth International Conference of Earthquake Engineering and Seismology, May Tehran, Islamic Republic of Iran, pp. 12-14. 